\title{
Jak se rodí profese: příklad kariérového poradenství1
}

\author{
Lenka Hloušková \\ Masarykova univerzita, Filozofická fakulta
}

\begin{abstract}
Abstrakt: Kariérové poradenství jako jedna z nově se etablujících pomáhajících profesí prochází i po více než 120 letech svého vývoje procesem profesionalizace. S oporou o definice kariérového poradenství, které se užívají v posledních 20 letech a pokrývají americkou i evropskou tradici, je kariérové poradenství v textu vymezováno jako povolání a jako služba. $\mathrm{Na}$ pozadí tohoto, do jisté míry umělého, odlišení povolání a služby je sledován cíl této studie, kterým je představit variabilitu náhledů na profesionalitu v kariérovém poradenství a popsat dva proudy $\checkmark$ profesionalizaci kariérového poradenství v českém prostředí. Jedním z nich je profesionalizace ve smyslu posunu od povolání k profesi, která stojí na teoriích, z nichž se vyvozují různé podoby odborné expertizy kariérových poradců. Druhý proud je ztotožněn s profesionalizací veřejných služeb, která probíhá tzv. shora jako institucionalizace poradenských služeb a tzv. zevnitř jako institucionalizace profesní komunity.
\end{abstract}

Klíčová slova: kariérové poradenství, profese, povolání, profesionalizace, profesionalita

\section{How a Profession Emerges: The Case of Career Guidance}

Abstract: Career guidance and counselling, even though its beginnings can be traced some 120 years back, is still undergoing professionalization as a helping profession. Selected definitions from the recent two decades covering the American and European traditions provide a basis for defining career guidance and counselling as an occupation and a service. On the background of this - to a certain extent artificial - distinction between occupation and service, the goal of this article is pursued: to present variations in understanding professionalism in career guidance and counselling, to describe two directions in career guidance and counselling professionalization in the Czech environment. The first of that - professionalization in the sense of shifting from an occupation to a career guidance profession has a firm basis in theory and related professional expertise of career counsellors. The second of that - professionalization of career guidance services is happening as a top-to-bottom process of institutionalization of guidance and counselling services and as internally as professional community institutionalization.

Keywords: career guidance, career counselling, profession, vocation, professionalization, professionalism

Společným znakem pomáhajících profesí je profesionální pomáhání. V čem spočívá profesionalita jejich pomáhání a která povolání považovat za profese? Sociologie práce vnáší mezi koncept povolání a koncept profese proces profesionalizace, což znamená, že ne každé povolání je automaticky profesí. Které ano a které ne? Odpo-

1 Studie vznikla za podpory projektu GA MU „Výzkum procesů učení: od formálního vzdělávání k informálnímu učeni““ (MUNI/A/1357/2018). 
46 vědi nebývají jednoznačné a v čase se mění podle toho, jak jsou vymezovány profese a profesionalita.

Cílem této studie není posuzovat, jestli kariérové poradenství je, nebo není profesí, ale přibližit, jak lze nahližet profesionalitu v kariérovém poradenství a popsat specifika procesu stávání se profesí, tj. procesu profesionalizace kariérového poradenství v českém prostředí, který s novou intenzitou probíhá přibližně od přelomu tisíciletí.

\section{Základní koncepty: profese, profesionalita, profesionalizace}

Tradiční sociologický přístup při vymezování profesí uplatňuje principy sociální stratifikace, což vede k zdůrazňování řady atributů, kterými se profese odlišují od povolání a současně mezi sebou. Profesemi se stávají jen povolání, která se profesionalizovala, tj. „naplnila“ jednotlivé atributy symbolizující sociální prestiž, moc, autonomii a také uzavřenost profesní komunity vưči jiným. I když se soubory znaků profesí v čase mění a rozpracovávají se (např. Despotovič, 2012; Greenwood, 1957; Ornstein \& Levine, 2008), období fascinace „klasickými“ profesemi končí začátkem šedesátých let 20. století (Štech, 2007).

V pomáhajících profesích toto vymezení profese do jisté míry přetrvává (kupř. Despotovič, 2012; Křižzvá, 2006; Ornstein \& Levine, 2008), a tak profesionalizace jako proces nabývání sociálního statusu profese (Evetts, 2013; Greenwood, 1957; Suda, 1996) může být i pro současné kariérové poradenství relevantní. Profesionalizace $v$ tomto smyslu totiž přináší př́slušníkủm dané profese řadu výhod, jako jsou jistota existence pracovních míst, perspektiva profesního rozvoje, sociální moc a v určitém smyslu zisk či hmotné zajištění. Obecně ale pro pomáhající profese platí, že snahy profesionalizovat se bývají považovány za úspěšné, pokud se podaří prosadit do legislativy výhradní právo př́islušníků té které profese vykonávat služby na přesně vymezené úrovni nebo $v$ dané kvalitě (srov. Suda, 1996).

$V$ sociologii práce se $\mathrm{k}$ vymezení profesí přistupuje i jinak. $Z$ hlediska kariérového poradenství se zdá relevantní uvažovat o profesi na základě protikladu mezi expertizou a amatérismem (Freidson, 1989; Suda, 1996). Profese reprezentují odbornost, která se projevuje spolehlivým a na určité expertize založeným pracovním výkonem $\checkmark$ konkrétně vymezených souborech činností vykonávaných za mzdu (zaměstnání). V tomto případě lze považovat pojmy profese a povolání za synonyma (Baláž, 2017; Freidson, 1989; Suda, 1996). ${ }^{2}$

Kdo, nebo co rozhoduje o tom, který výkon je odborný / na expertize založený, a tím i profesionální? Zárukou a současně i předpokladem očekávaného - profesionál-

2 Povolání je v ČR vymezeno i legislativně jako „standardizovaný souhrn pracovních činností podle jejich obvyklého seskupení na trhu práce, jejichž výkon předpokládá určitou odbornou a další způsobilost" (zákon o zaměstnanosti, 2004, § 5 písmeno f). 
ního - výkonu je vzdělání, kterým jedinec získává specifické vědomosti, dovednosti a postoje. Freidson (1989) je ale přesvědčen, že o profesionalitě rozhoduje profesní komunita, která si „přisvojuje“ právo kontrolovat pracovní výkon, vzdělávání, vstup do profese a celou řadu dalších aspektů u těch, kteří chtějí být, nebo deklarují, že již jsou př́slušníky dané profese. Profesionalita v tomto př́padě vychází ze sdílených hodnot a postojů v profesní komunitě, což profesní komunitě umožňuje vykonávat dohled nad profesí. Evettsová (2003, 2011, 2013) tento typ profesionality, který vychází ze shody př́slušníků profese na tom, v čem expertiza spočívá, a kterou pak př́slušníci profese $v$ rámci svého zaměstnání kontrolují, nazývá profesní profesionalitou (occupational professionalism) ${ }^{3}$.

Profesionalita, a zvlášt' v prípadě pomáhajících profesí, je v současnosti nahlížena i jako diskurz, který vytvářejí členové profesní komunity, zaměstnavatelé těchto profesionálů, jejich klienti i širší veřejnost. Podoba diskurzu je z hlediska vymezení profesionality významná tím, že se stává základem sdílené profesionality mezi všemi aktéry diskurzu. Sdílená profesionalita se pak za určitých podmínek mưže stát „tou pravou“, tzv. normativní profesionalitou (srov. Evans, 2008; Evetts, 2013). Normativní profesionalita má mnoho podob a dá se rozlišit profesionalita vyžadovaná (klienty, zaměstnavateli, členy té které profesní komunity...), předepsaná nebo předpokládaná (Evans, 2012). Pokud by se normativní profesionalita zúžila pouze na organizace, kde nacházejí uplatnění príslušníci dané profese, pak je nezbytné, aby organizace na sebe převzaly závazek dohledu a kontroly pracovního-profesionálního výkonu, což v terminologii vede $\mathrm{k}$ ztotožnění pojmů povolání a profese (srov. Baláž, 2017). Vzhledem $\mathrm{k}$ tomu, že zaměstnanci jedné organizace nemusí být výhradně příslušníky jedné profese, je pravděpodobné, že diskurz profesionality se liší mezi organizacemi, a proto Evettsová $(2011,2013)$ rozvíjí úvahy o tzv. organizační profesionalitě.

I když je profesionalita vymezována různě, stává se předmětem výzkumu nejen v podobě souboru očekávání, hodnot a norem vztahujících se k expertnímu výkonu a každodennímu chování př́islušníků dané profese (Baláž, 2017; Evetts, 2003; Juklová, 2013; Křížová, 2006), ale také reálných postupů, jež „jsou ve shodě s obecně přijímaným vymezením určité profese, které reflektují status dané profese, její cíle a specifika..., které odrážejí úroveň služeb, jež tato profese poskytuje a které $\checkmark$ jejích postupech převažují, stejně jako etický kodex, jímž se daná profese řídí“ (Evans, 2012, s. 132). V českém prostředí se profesionalita zkoumá u různých pomáhajících profesí (např. Baláž, 2017; Křížová, 2006; Pišová et al., 2013), ale u českých kariérových poradců dosud zkoumána nebyla.

3 Příkladem profesní komunity, která různými způsoby a na rozličných úrovních podporuje sdílení toho, co je profesionální, múže být komunita učitelů. I když jsme svědky variability náhledu na profesionalitu učitelů, shoda je v tom, že učitel je expert na vzdělávání žáků. Alespoň tato elementární shoda posiluje profesní komunitu učitelů v dohledu nad výkonem profese, tj. kontrola a dohled jsou založeny na kolegiální autoritě. To znamená, že učitelé, jakmile se stanou př́slušníky profese (splní vstupní podmínky do profese a vykonávají ji), dostávají v rámci náplně své práce (v zaměstnání) prostor k dohledu nad výkonem profese. Současně je pochopitelné, že se komunita učitelů snaží dohled nad výkonem profese odstupňovat a formalizovat (viz např. kariérní rád učitelů, legislativou nastavené podmínky výkonu funkce ředitele školy). 
Kariérové poradenství nahlížené jako soubor pracovních činností, $\mathrm{k}$ jehož výkonu je nezbytné získat odbornou způsobilost, je značně diferencované. Rozmanitost souvisí s jednotlivými sociálními reformami (Neukrug, 2012), stejně tak jako s historickými rozkoly mezi různými vědními obory, např. sociologií, sociální prací, ekonomií, psychiatrií, ale specificky souvisí s diferenciací oboru psychologie a vývojem aplikované psychologie jako základního oboru spojovaného s poradenstvím (Neukrug, 2012; Van Esbroeck \& Athanasou, 2008).

Po sérii výzkumů služeb kariérového poradenství v nejrůznějších zemích světa (CEDEFOP, 2009a; Hansen, 2007; Hloušková et al., 2004; Kuczera, 2010; OECD, 2010; Watts, 1994; Watts \& Sultana, 2004) se ukázalo, že činnosti poskytovatelů, kteří se považují, nebo jsou označováni jako kariéroví poradci, jsou velmi různorodé a často se odvíjí od původních profesí kariérových poradců (učitel, psycholog, informatik, kariérový poradce). Tento fakt by naznačoval, že kariérové poradenství jako povolání neexistuje.

S ohledem na výše uvedené a cíl textu popsat specifika procesu profesionalizace kariérového poradenství v českém prostředí je potřeba vědět, v čem spočívá expertiza kariérových poradců, což lze přibližit skrze činnosti (povolání), které jsou s kariérovým poradenstvím spojovány a které vycházejí z jednoznačných teoretických východisek. Pro tyto účely byly vybrány definice, jež zahrnují očekávané i empiricky dokladované činnosti kariérových poradců a současně reprezentují americkou i evropskou tradici kariérového poradenství. Americká tradice (Amundson, 2009; Hiebert, 2009; Peavy, 2013; Savickas, 2003) totiž vnáší do procesu profesionalizace jiné otázky než tradice v evropských zemích (CEDEFOP, 2005, 2009a; Hooley, Sultana, \& Thomsen, 2018; McCarthy, 2004; Nilsson \& Åkerblom, 2001; OECD, 2004a, 2004b; Rada Evropské unie, 2008; Sultana, 2004) sdružených v Evropské unii, ke kterým má ČR geograficky, historicky i svým členstvím v EU blíž. Do souboru definic byla zahrnuta i „národni““ vymezení (Hloušková et al., 2004; Svobodová, 2015; Vendel, 2008). Časově byl výběr definic omezen na posledních 20 let, což zachycuje proměnu kariérového poradenství v kontextu globalizace (Savickas, 2008), která byla v českém prostředí umocněna vstupem ČR do EU.

\subsection{Soubory činností kariérových poradců}

Pro přehlednost a vyjasnění podob profesionality pomáhání jsou jednotlivé skupiny činností kariérových poradců popisovány zvlášt'.

Práce s kariérovými informacemi. Kariéroví poradci mohou pomáhat tím, že shromažd'ují, třídí, zpř́stupňují a poskytují informace významné pro rozhodování, změnu i rozvoj kariéry. Poskytování informací bylo vždy nedílnou součástí práce kariérových poradců (OECD, 2004a, 2004b; Watts, 1994), ale postupně se práce s informacemi vyčleňuje jako samostatný soubor činností (career advising), který je předpokladem poskytování služeb kariérového poradenství (např. Hansen, 2007; OECD, 2010). 
V podstatě se jedná o nepersonalizovanou práci s informacemi, které jsou v určitých podobách zpř́stupňovány a šířeny mezi cílové skupiny zájemců o informace. Nástrojem pomáhání jsou v tomto př́padě způsoby komunikace (tj. základem profesionality jsou teorie komunikace), nikoli vztah mezi poradcem a klientem, což je také jeden $z$ argumentů, proč kariéroví poradci při těchto činnostech běžně využívají moderních technologií a proč jsou tyto činnosti poskytovány $v$ podobě sebeobslužných služeb. Vyčleňování práce s informacemi do samostatného souboru aktivit vede $k$ vymezení samostatné pracovní role kariérových poradců (Schiersmann et al., 2012), což otevírá prostor pro zavedení profese s názvem career advisor (OECD, 2010).

Pokud bychom uvažovali o tomto souboru činností jako náplni práce kariérového poradce zaměstnaného na plný pracovní úvazek v nějaké organizaci v ČR, pak je ž̌ejmé, že by se od takového pracovníka očekávalo poskytování nepersonalizovaných i personalizovaných kariérových informací. To znamená, že tento kariérový poradce by měl znát zdroje takovýchto informací (nejlépe je i vytvářet), mít přehled o možnostech práce s nimi a měl by umět vytvořit z nepersonalizovaných informací soubor informací podle potřeb a požadavků konkrétních klientů, které by následně poskytoval cílovým skupinám klientů dané organizace. Uvedené spojení mezi popisovaným souborem činností a působením kariérového poradce $v$ konkrétní organizaci může být př́kladem tzv. předepsané profesionality (Evans, 2012), kterou lze v českém prostředí považovat spíše za vizi než realitu.

„Zaměstnanecké“ poradenství. Tento typ činností se z hlediska klientely týká pouze dospělých a zahrnuje zprostředkovávání volných pracovních míst, vyhledávání, výběr i nábor zaměstnanců (recruitment), rozmist’ování/umist'ování pracovníků a plánování nástupnictví na pracovišti (placement), podporu při propouštění zaměstnanců (outplacement) a podporu rozvoje kariéry obecně / kariérového rozvoje na pracovišti (srov. CEDEFOP, 2009a; Hansen, 2007; OECD, 2004a). Soubor uvedených činností (employment counselling), které se v evropských zemích (včetně ČR) soustřed'ují do sféry služeb zaměstnanosti (Vuorinen \& Kettunen, 2017), se dostává do vleku ekonomické stability a prosperity společnosti, což odklání kariérové poradenství od humanistického základu poradenství (srov. Peavy, 2013).

Profesionalita kariérových poradců se $v$ tomto prípadě odvíjí od dosahování poradenských cílů zasazených do kontextu rozvoje lidských zdrojů a od dílčích výsledků poradenské práce, které jsou nahlíženy prismatem ekonomického profitu jedince, firmy, společnosti (tj. profesionalita stojí na teoriích rozvoje lidských zdrojů, teoriích efektivity či návratnosti různých typů kapitálu...). To sice kariérovým poradcům „zachovává“ roli aktéra změny jedince i společnosti (Banks \& Martens, 1973), ale současně to profesi kariérového poradenství dostává do rozporu s posláním pomáhajících profesí - poskytovat nezištnou pomoc druhým. $V$ českém prostředí tento rozdíl ve filozofii a př́stupu k pomáhání vede k odlišování kariérového poradenství a personalistiky.

Kariérové vzdělávání. Kariérové vzdělávání (career education) je v českém prostředí tradičně spojováno s profesní orientací (Koščo et al., 1986; Svobodová, 2015). Pokud se v kariérovém vzdělávání oddělí poradenské a vzdělávací činnosti, pak se 
$50 \vee v$ češtině pro vzdělávací činnosti vžilo sousloví výchova $\mathrm{k}$ (volbě) povolání a $\mathrm{k}$ práci, kterou obvykle realizují učitelé v rámci formálního vzdělávání (Vendel, 2008). Naopak podpora profesní orientace, která je spojována s poradci, prioritně psychology, stojí na diagnostice a probíhá $v$ poradnách. Diagnostika $v$ různých oblastech, ale dnes spíše sebepoznávání a sebereflexe klienta je základem dalšího edukativního působení kariérových poradců (career educators).

V evropské tradici se na soubor činností označovaných jako kariérové vzdělávání klade zvýšený důraz a v současnosti se jedná o základní náplň práce kariérových poradců. Profesionalita kariérového vzdělávání spočivá ve vzdělávání a dalších možnostech podpory učení jedince (tj. profesionalita vychází z teorií vzdělávání a teorií učení). Společným cílem těchto činností je rozvoj dovedností (prioritně career management skills) a kompetencí, které umožní jedincům dělat informovaná rozhodnutí a řídit svou kariéru (CEDEFOP, 2005; OECD, 2004b; Rada Evropské unie, 2008). V souvislosti s prosazováním konceptu celoživotního učení v evropských zemích (Evropská komise, 2004) se kariérové vzdělávání stává jedním z důležitých nástrojů, jak učinit celoživotní učení realitou (Rada Evropské unie, 2008), a jednou $\mathrm{z}$ př́ležitostí $\mathrm{k}$ učení, která by měla být přístupná každému, $\mathrm{v}$ každém prostředí i každém bodě života jedince (CEDEFOP, 2010).

„Vlastni““ kariérové poradenství. V souboru těchto činností lze rozlišit krátkodobé, často jednorázové, intervence, jejichž cílem je zorientovat jedince (guidance) v konkrétní situaci, v náhledu na sebe, v existujících př́ležitostech či možnostech volby a vést ho, aby mohl učinit informovanou a zodpovědnou volbu (Hloušková et al., 2004; OECD, 2004a, 2004b). V rámci činností typu guidance se rozlišují činnosti podporující jedince při rozhodování se o povolání, profesním zaměěení či výběru konkrétního zaměstnání a ty jsou označovány tradičním pojmem - profesní poradenství (vocational guidance). Podpora při rozhodování o vzdělávací dráze, výběru konkrétního typu vzdělávání, školy nebo studijního oboru je označovaná pojmem výchovné poradenství (educational guidance; Hansen, 2007).

Činnosti typu guidance probíhají v podobě konzultací nebo jako poradenský rozhovor zaměřený na řešení, kde poradce zaujímá roli experta. Expertiza kariérového poradce spočivá ve znalostech celého spektra možností a př́ležitostí, které by mohl jedinec využít, a současně v přizpůsobování podpory klientům při využivání vybraných možností/př́ležitostí. Teoretická východiska tohoto typu poradenské práce představují koncepty kariéry a poradenské teorie zaměřené na úkol/řešení.

Vedle činností typu guidance se rozlišují ty, jejichž cílem je podpora kariérového rozvoje jedince (counselling ${ }^{4}$ ), at' už ve smyslu podpory jedince při překonávání překážek v jeho kariéře, nebo podpory ve smyslu ř́zení své kariéry (srov. Hansen, 2007; Hiebert, 2009; Nilsson \& Åkerblom, 2001; Peavy, 2013; Savickas, 2008; Vendel, 2008). Podpora kariérového rozvoje se děje skrze „zmocňováni““, tj. posilování potenciálu rozvoje klienta např. tím, že poradce pomáhá jedinci utvářet/

4 Pojmy guidance a counselling nevyjadřují jen rozdíly v souborech činností kariérových poradců, ale reprezentují i lingvistické a regionální odlišnosti zakotvené v odlišných teoretických východiscích (srov. Van Esbroeck \& Athanasou, 2008). 
uvědomovat si hodnoty, zásady a další vnitřní kritéria, na jejichž základě se lidé rozhodují, participují na životě společnosti, řídí a plánují své životy (srov. Peavy, 2013). Základním teoretickým východiskem tohoto typu poradenské práce jsou teorie kariérového rozvoje, které pracují s předpokladem, že klient aktivně pracuje sám na sobě a svém rozvoji (Amundson, 2009). Činnosti typu counselling jsou výrazem starosti a péče o sebe i o druhé a expertiza kariérového poradce spočívá v pomáhání skrze profesionální vztah mezi poradcem a klientem (srov. Amundson, 2009; Peavy, 2013; Sharf, 2013).

Proměna činností typu counselling kopíruje vývoj humanistických teorií v psychologickém poradenství a teorií kariérového rozvoje, které byly kontinuálně přehodnocovány $v$ důsledku měnících se požadavků světa práce i společnosti. Výsledkem toho je vznik zcela nových teorií, a to teorií kariérového poradenství (Mcllveen \& Patton, 2006; Sharf, 2013). Existence teorií kariérového poradenství a modelů poradenské práce, které z nich vyrůstají, jsou považovány za silnou stránku kariérového poradenství a za hlavní argument, proč je kariérové poradenství v americké tradici považováno za zdravou profesi (Niles, 2003).

Soudobé kariérové poradenství typu counselling se snaží nahradit direktivní a výhradně psychologickou pomoc jedinci v průběhu jeho kariérového rozvoje nedirektivní podporou rozvoje kariéry jedince (Patton \& McMahon, 2006), do které jsou přizýváni i príslušníci dalších profesí. Nedirektivní podporu je možné si představit jako facilitaci kariérové rozvoje (Alan \& Moffett, 2016), kterou lze kombinovat s mentoringem nebo koučinkem. Mentoring ani koučink nepředstavují práci kariérového poradce (Niles, 2003), ale v poradenské praxi některých kariérových poradců se prolínají. Využívání dalších profesionalizovaných činností v práci kariérového poradce, jako např. zmíněný mentoring nebo koučink, oslabuje snahy profesionalizovat povolání kariérového poradenství. $V$ posledních letech nedirektivní proud $v$ činnostech typu counselling akcentuje narativní postupy (Maree, 2010; Sharf, 2013), čímž dává základ vzniku dalším teoriím kariérového poradenství, jako je např. life-design counselling (Savickas et al., 2009), což znovu posiluje tendenci profesionalizovat povolání kariérového poradenství směrem k profesi.

\subsection{Nástroje profesionalizace}

Předpokladem proměny povolání v profesi je jasně vymezená profesionalita v souboru pracovních činností, jejichž výkon si vyžaduje určité vzdělání, které vytváří nebo alespoň „přenáši“ expertizu na základě existujících teorií. $Z$ tohoto úhlu pohledu je základním nástrojem profesionalizace kariérového poradenství vzdělávání, konkrétně vysokoškolské vzdělání, které pokračuje v podobě profesního rozvoje každého kariérového poradce.

Vzdělávání poradců. Pokud má být vzdělávání nástrojem profesionalizace, musí být velmi úzce navázáno na vyžadovanou profesionalitu bud' v podobě souboru vědomostí, dovedností a postojů, kterými by měl být kariérový poradce vybaven před vstupem do profese a v průběhu praxe, nebo v podobě kompetencí, které kariéro- 
52 vému poradci umožní profesionálně zvládat situace, do kterých se při výkonu své praxe dostává (srov. Hloušková, 2018).

Na první pohled se může zdát, že se príprava kariérových poradců (zejména ve smyslu pregraduální př́ípravy na vysokých školách) neliší od jiných poradců. Opak je ale pravdou. Základní odlišnost se odvijí od teorií kariérového poradenství a v současné době i od cílů, které do prrímé práce s klienty vnesly politické dokumenty (CEDEFOP, 2005, 2010; Evropská komise, 2004; Rada Evropské unie, 2008). Na druhou stranu jsou teorie kariérového poradenství a prioritně teorie kariérového rozvoje oborově zakořeněny $v$ psychologii, která $v$ současné době přestává být oborem, na kterém by stálo vzdělávání budoucích kariérových poradců (CEDEFOP, 2009b). Dokonce u kariérových poradců, kteří působí v odborném vzdělávání, je psychologizující příprava předmětem kritiky (Kuczera, 2010; OECD, 2010). Další oblastí príípravy poradců pro prímou práci s klienty jsou, ale ne specificky pro kariérové poradce, poradenské dovednosti (Sharf, 2013).

Bohužel v ČR se vzdělávání jeví jako velmi slabý nástroj profesionalizace kariérových poradců. Neexistuje totiž systém vzdělávání kariérových poradců (srov. Hloušková, 2018), který by kopíroval vyžadovanou profesionalitu. Stále chybí specializované vysokoškolské vzdělání, které by zajistilo prípravu pro výkon povolání kariérového poradce v nezbytné teoretické hloubce (srov. CEDEFOP, 2009b; Hloušková et al., 2004), a v češtině je jen velmi omezená nabídka vzdělávacích příležitostí, které by cíleně stavěly na teoriích kariérového rozvoje. $Z$ tohoto úhlu pohledu je dnešní kariérové poradenství v ČR okleštěnou profesí (Sultana, 2004).

Vstupní kvalifikaci kariérového poradce lze $v$ ČR získat bud' dosažením vyššího odborného či bakalářského stupně vzdělání s preferencí vybraných studijních oborů (MPSV, 2019), nebo na základě přezkoušení autorizovanými osobami a uznáním neformálního vzdělávání (NúV \& Trexima 2015a, 2015b, 2015c55). Uznávání neformálního vzdělání se z hlediska profesionalizace jeví jako nástroj omezení vstupu do profese, ale $v$ ČR není zaměstnavateli vyžadováno ani předepsáno pro žádnou oblast veřejných služeb, kde kariéroví poradci působí. Kontinuální nabývání profesionality či spíše profesní rozvoj - kariérových poradců je otázkou individuální zodpovědnosti každého, kdo se chce $v$ této oblasti profesně angažovat, což je mj. projevem slabé kontroly ze strany profesní komunity.

Profesní komunita. Variabilita činností kariérových poradců, různorodost jejich pregraduální př́pravy a také resortní etablovanost zaměstnavatelů kariérových poradců umocňují rozdrobenost profesní komunity (kariérový poradce, který vzdělává; kariérový poradce, který zpracovává a poskytuje informace; kariérový poradce, který pracuje s tou kterou cílovou skupinou; kariérový poradce, který působí jako osoba samostatně výdělečně činná nebo jako zaměstnanec; atd.), jež by fungovala na sdílené profesní profesionalitě, tj. profesionalitě založené na shodě členů profesní komunity o expertním výkonu práce.

5 Zmiňované kvalifikační a hodnoticí standardy aktuálně procházejí revizí. 
Kroků, které byly $v$ ČR učiněny za účelem formování komunity kariérových poradců, je celá řada. $V$ současné době fungují dvě profesní sdružení. V roce 2015 byla založena Česká asociace kariérového poradenství, o dva roky později zahájilo činnost Sdružení pro kariérové poradenství a kariérový rozvoj a byla založena Expertní komora kariérového poradenství. V roce 2016 byla založena tradice národních konferencí s ambicí intenzivněji integrovat české kariérové poradce do evropského prostoru.

Významným úspěchem komunity kariérových poradců z hlediska profesionalizace bylo nedávné přijetí charakteristiky povolání kariérového poradce včetně požadavků pro výkon pracovních činností kariérových poradců do Národní soustavy povolání (Národní poradenské fórum, 2013; MPSV, 2019) a do Národní soustavy kvalifikací (NúV \& Trexima, 2015a, 2015b, 2015c). Výzvou ale zůstává vzdělávání kariérových poradců před vstupem do profese, konkrétně nabídka studijního oboru nebo studijního programu na vysokých školách.

Uvedené aktivity a samožrejmě i řada dalších jsou projevem života profesní komunity, ale k sdílené profesní identitě nebo alespoň souboru hodnot, které by byly základem profesní profesionality, zatím profesní komunita kariérových poradců nedospěla.

Profesní identita. Pokud přijmeme fakt, že $v$ ČR poskytují služby kariérového poradenství odborníci, kteří získali odbornou způsobilost / kvalifikaci kariérového poradce $v$ rámci dalšího profesního vzdělávání nebo na základě uznání výsledků celoživotního učení (konkrétně neformálního vzdělávání), přetrvává otázka, jestli se tito odborníci identifikují s kariérovým poradenstvím, tj. cítí se kariérovými poradci. ${ }^{6}$

Z hlediska profesní identity se dá předpokládat, že kariéroví poradci, kteří dnes působí ve veřejných službách (služby zaměstnanosti, sociální služby obvykle poskytované neziskovými organizacemi a poradenské služby ve školách a školských poradenských zařízeních), se mohou cítit profesionály v duchu svého pregraduálního vzdělávání nebo příslušníkem regulované profese7, tj. cítí se být „více“ psychologem, sociálním pracovníkem, učitelem než kariérovým poradcem.

Regulace profese. V ČR nejsou legislativně vymezeny požadavky na výkon povolání/profese ani podmínky výkonu práce kariérových poradců. Profesionalita kariérových poradců je ve veřejných službách kontrolována a současně garantována prostřednictvím nástrojů využívaných v tzv. regulovaných profesích, mezi které kariérové poradenství nepatří. Na druhou stranu zmínek o výše zmiňovaných činnostech kariérových poradců je v legislativě celá řada (kupř. v činnostech Úřadu práce ČR, viz zákon č. 73/2011 Sb., o úřadu práce, nebo zákon č. 435/2004Sb., zákon

6 Profesní identitě kariérových poradců se zatím žádný výzkum v ČR nevěnoval. S jistou dávkou fantazie by se ale dalo s oporou o existující šetření mezi výchovnými poradci spekulovat o profesní identitě výchovných/kariérových poradců na základních a středních školách. V ČR totiž bylo opakovaně mapováno spektrum činností výchovných poradců, do jisté míry i jejich vzdělávací potřeby, ale především se věnovala pozornost podmínkám a nárokủm na práci výchovných poradců (např. Drahoňovská \& Eliášková, 2011; Ehlová, 2016; Zapletalová, 2003; ankety mezi členy Asociace výchovných poradců, nepublikované disertační práce na toto téma).

7 Regulovaná povolání jsou taková, pro jejichž „výkon jsou v České republice předepsány právními předpisy požadavky, bez jejichž splnění nemǔže osoba toto povolání či činnost vykonávat (kvalifikační požadavky, případně bezúhonnost, zdravotní zpưsobilost a další)“ (MŠMT ČR, 2011). 
54 o zaměstnanosti, i v pozdějších úpravách, anebo explicitně uvedená povinnost poskytovat kariérové poradenství ve školách a poradenských zařízeních - viz vyhláška č. 197/2016 Sb., o poskytování poradenských služeb ve školách a školských poradenských zařízeních, a některé další vyhlášky). Na národní úrovni ale chybí i další nástroje regulace výkonu práce kariérových poradců, např. profesní standardy nebo etický kodex profese ${ }^{8}$, kterými by profesní komunita a skrze ni i stát mohly kontrolovat a garantovat profesionalitu práce kariérových poradců.

$\checkmark$ předcházející části textu bylo kariérové poradenství představeno jako povolání, pro které je typická pestrost pomáhajících činností (help, assist, support). S přihlédnutím ke specifikům kariérového poradenství (vývoj teoretických východisek, geografické rozdíly, provázanost s trhem práce) je variabilita činností spojovaných s kariérovými poradci výrazně diferencujícím prvkem, což brání obvyklým nástrojům profesionalizace, které má k dispozici profesní komunita, plně se prosadit a vyzdvihnout kariérové poradenství mezi profese.

Mnozí představitelé komunity kariérových poradcůa ale usilují o dosažení další mety na cestě od povolání k profesi, a to o prosazení sdílené podoby expertnosti jako profesní hodnoty, která by všem kariérovým poradcům pomohla obhajovat pozici na trhu práce a mohla by být základem sdílené profesní profesionality. $Z$ tohoto úhlu pohledu může být jistou nadějí koncept nové profesionality (Evetts, 2011), v němž by organizační profesionalita, tj. profesionalita kariérového poradenství vytvářená $v$ té které organizaci, kde jsou kariéroví poradci zaměstnáni společně s jinými profesionály, reagovala na výzvy ${ }^{10}$, před kterými stojí kariéroví poradci den co den, když poskytují služby kariérového poradenství. Otázkou ale zůstává, jak by tzv. nová profesionalita vypadala.

\section{Kariérové poradenství jako služba}

Kariérové poradenství jako služba je spojováno s prosazováním lidských a občanských práv, konkrétně s uplatňováním práva na práci, svobodnou volbu povolání/zaměstnání a ochranu v př́ípadě nezaměstnanosti (Evropské společenství, 1989, 2000; OSN, 1948, 1966; Rada Evropy, 1961, 1988, 1996), ke kterým se přidalo ne všemi evropskými státy přijaté právo na kariérové poradenství (Rada Evropy, 1996).

Pokud uvažujeme o kariérovém poradenství jako službách, pak se náhled na profesionalitu liší podle toho, $v$ jakém sektoru se služby kariérového poradenství nabízejí. Služby v soukromém sektoru fungují na tržních principech, proto odvozují profesionalitu od (klienty) vyžadované profesionality. Ve veřejných službách, kde

8 Česká asociace kariérového poradenství má svůj Etický kodex (2015), ale tento kodex se netýká přímé poradenské práce. Kariéroví poradci jsou ve své praxi odkázáni na etické kodexy svých mateřských profesí, poradenských asociací, v nichž jsou sdružení, či určitého typu služeb, které zahrnují činnosti kariérových poradců.

9 Aktuálně jsou v této věci aktivní především členové Sdružení pro kariérové poradenství a kariérový rozvoj a mnozí členové Národního poradenského fóra.

10 Hlavními výzvami, před kterými kariérové poradenství stále stojí, je proměnlivost trhu práce, multikulturní společnost, nestabilita a tím i vzrůstající nejistota v životech jednotlivců. 
čeští kariéroví poradci nacházejí své uplatnění mnohem častěji, se s odkazem na principy rovnosti / rovných př́ležitostí, sociální spravedlnosti a občanské angažovanosti, které jsou obsaženy $v$ dokumentech sociální politiky (politiky zaměstnanosti i vzdělávací politiky), rýsuje základ předepsané profesionality, která ale reálně v ČR chybí.

V kariérovém poradenství vymezovaném jako veřejná služba ustupuje do pozadí pomáhání jedinci-klientovi/zákazníkovi při kariérovém rozhodování a rozvoji dovedností řídit a plánovat svou kariéru (Evropská komise, 2004) a upřednostňuje se uschopňování jedinců-občanů identifikovat své schopnosti, kompetence a zájmy, rozhodovat se a řídit život podle svých potřeb a v souladu se svými právy (Rada Evropské unie, 2008). To znamená, že cíl poradenské práce se $v$ dokumentech sociální politiky posouvá od přímé pomoci klientovi-zákazníkovi k posilování vztahu mezi státem a občanem, aby občan dokázal a chtěl participovat na životě společnosti (srov. Sultana, 2011).

$\mathrm{V}$ tomto smyslu se kariérové poradenství stává nástrojem řady politik, konkrétně hospodářské politiky, politiky zaměstnanosti, vzdělávací politiky a specificky v zemích EU i nástrojem politiky celoživotního učení, což vyústilo v označení kariérového poradenství jako lifelong guidance (CEDEFOP, 2010; Evropská komise, 2004; Rada Evropské unie, 2008). Pomyslná smlouva mezi státem a občany, která v současnosti směřuje $\mathrm{k}$ inkluzivní společnosti, se projevuje důrazem na sociální (nikoli individuální) dobro (Sultana, 2011) a soudobé kariérové poradenství

podporuje jednotlivce i skupiny v prozkoumávání světa práce, volného času a učení, v uvažování o jejich místě ve světě a v plánování své budoucnosti. Kličem $\mathrm{k}$ takto zaměřené podpoře je rozvoj individuálních i komunitních kapacit analyzovat a problematizovat předpoklady a mocenské vztahy, sít’ovat, budovat solidaritu a vytvářet nové a sdílené př́ležitosti. (Hooley et al., 2018, s. 20)

Proto, aby bylo možné naplňovat vize společnosti, $\mathrm{k}$ nimž má směřovat i kariérové poradenství, byl pro služby kariérového poradenství nastaven požadavek dostupnosti služeb pro každého a v každém bodě jeho života (Evropská komise, 2004; OECD, 2004a, 2004b; Rada Evropské unie, 2008). Široce nastavená dostupnost služeb kariérového poradenství $v$ rámci veřejných služeb je ale $v$ rozporu $s$ vysokou mírou expertnosti, která ve svém důsledku musí činit z profese nedostatkové zboží. Dưraz na dostupnost služeb kariérového poradenství představuje z hlediska profesionality ve smyslu odbornosti / odborné expertizy deprofesionalizační tendenci, ale v diskurzu sociální politiky, kde je dostupnost služeb zárukou uplatňování/prosazování celé řady práv, je profesionalita spojována s konceptem kvality služeb.

\subsection{Profesionalizační procesy}

Profesionalizace kariérového poradenství jako služby je spojena s institucionalizací, a to ve třech rovinách: na národní úrovni skrze regulaci veřejných služeb (Vuorinen \& Kettunen, 2017), v rovině organizace skrze organizační profesionalitu (Evetts, 
$562003,2011,2013)$ a v rovině profesní komunity skrze kulturu profese ${ }^{11}$ (Evans, 2012; Grenwood, 1957).

Domnívám se, že profesionalizace kariérového poradenství jako služby může být úspěšná, pokud bude probíhat skrze jednu, všem úrovním společnou hodnotu. Hodnotou, která je obsažena ve vyžadované profesionalitě ve veřejných službách, reprezentuje organizační profesionalitu $v$ organizacích poskytujících služby kariérového poradenství a má své místo ve formující se kultuře profesní komunity, je kvalita poradenské práce.

Institucionalizace poradenských služeb. Jednou z možností, jak institucionalizovat kvalitu poradenské práce na národní úrovni, je skrze zavedení standardů kvality, z nichž vycházejí nástroje regulace poradenských služeb. V ČR chybí národní standard kvality a dosud ani nebyl zaveden žádný z nástrojů regulace/garantování kvality služeb kariérového poradenství. Na národní úrovni se po vzoru jiných evropských zemí nabízí možnost legislativního ukotvení předpokladů a podmínek poskytování služeb, implementace standardů kvality, př́padně regulování výkonu profese prostřednictvím udělování licencí, anebo vedením registru poradců (srov. Vuorinen \& Kettunen, 2017).

Jiný př́klad implementace kvality poradenských služeb může vycházet z vazeb mezi kvalitou služeb (ztotožněnou s profesionalitou) a kvalitou organizace, kde se služby kariérového poradenství poskytují. $V$ tomto př́padě, tj. $v$ rámci institucionalizace kvality poradenské práce na úrovni organizace, je potřeba zohlednit kontext, ve kterém kariéroví poradci služby poskytují. To znamená, že je potřeba odlišit, jestli je kariérový poradce zaměstnancem, anebo osobou samostatně výdělečně činnou, a jestli vykonává práci kariérového poradce jako zaměstnanec $v$ rozsahu jednoho pracovního úvazku, nebo jestli se $v$ tom kterém př́padě jedná o profesní specializaci psychologa práce, personalisty, učitele či sociálního pracovníka.

Pokud kariérový poradce poskytuje službu kariérového poradenství „,na plný úvazek“ a jeho náplň práce spočívá $v$ přímé poradenské práci, je z pozice zaměstnavatele i klienta žádoucí (vyžadovaná profesionalita), aby do kvality byly zahrnuty principy poradenství poskytovaného tváří v tvář i zákonitosti distančního poradenství poskytovaného prostřednictvím e-mailu, skype, chatu apod. Pokud bude kariérový poradce poskytovat služby „na plný úvazek“, ale bude kombinovat př́mou a nepríimou poradenskou práci, tak se kvalita rozšiřuje o činnosti ve prospěch organizace $v$ souladu s organizační profesionalitou. $V$ případě služeb kariérového poradenství jde o činnosti jako sít’ování a management služeb zahrnující designování, marketing, fundraising a evaluaci služeb (srov. Schiersmann et al., 2012).

Institucionalizace profesní komunity. $V$ tomto př́ípadě jde o proces budování kultury profese, kterou vytváří a uvádí v život profesní komunita, pro niž je typická sdílená profesní identita a soubor hodnot, kterými vyjadřuje svůj náhled na to, co

11 Kultura profese se utváří mezi členy profesní komunity, kteří se cítí být reprezentanty dané profese, tj. mají společnou profesní identitu, přestože „zastupují“ nejrůznější sociální i zájmové skupiny napříč jednotlivými státy. Protože jsem přesvědčena, že profesní komunita kariérových poradců $v$ ĆR dosud svou kulturu profese nevytvořila, nebude uvedenému věnována pozornost. 
je kvalitní, a tím i profesionální. Kultura profese českého kariérového poradenství

se teprve formuje, a tak se pomyslně vracíme $\mathrm{k}$ profesionalizaci kariérového poradenství ve smyslu posunu od povolání k profesi.

\section{Závěr}

Kariérové poradenství ve srovnání s jinými pomáhajícími profesemi reprezentuje relativně nový obor lidské činnosti, a tak je pochopitelné, že jeho profesionalizace je i v ČR stále aktuální otázkou. Profesionalizace ze sociologického pohledu představuje vertikální sociální mobilitu, což může být důvodem, proč i čeští kariéroví poradci usilují o to, stát se př́slušníky své profese, a snaží se o profesionalizaci zevnitřr.

Profesionalizace zevnitř, ve smyslu posunu od povolání k profesi, o kterou usilují př́slušníci určitého povolání, stojí na sdílené podobě expertnosti (profesní profesionalitě) mezi členy profesní komunity, nebo na vyžadované profesionalitě, kterou by profesní komunita přijala. Variabilita činností kariérových poradců a jejich uplatnění $\checkmark$ různých sektorech veřejných služeb v ČR (poradenské služby ve školách a školských zařízeních, sociální služby a služby zaměstnanosti) ztěžuje dosažení shody na tom, $\checkmark$ čem spočivá profesionalita českého kariérového poradce. Sdílená podoba profesní profesionality, anebo alespoň souboru hodnot vztažených $\mathrm{k}$ profesionalitě, by určitě posunula dosavadní snahy profesní komunity kariérových poradců o formulaci normativní profesionality. Překážkou $\mathrm{k}$ tomuto cíli je rozdrobenost profesní komunity českých kariérových poradců, což současně oslabuje prípadné ambice této komunity institucionalizovat dohled a kontrolu nad vstupem do profese, vzděláváním i výkonem práce. Z uvedeného úhlu pohledu lze konstatovat, že povolání kariérového poradenství se od roku 2015 (NúV \& Trexima, 2015a, 2015b, 2015c) vydalo na cestu k profesi.

Druhá cesta, profesionalizace shora skrze institucionalizační procesy, si vyžaduje existenci normativní profesionality, která je $v$ ČR na národní úrovni vymezena jen částečně, ale existuje na organizační úrovni jako součást organizační profesionality. Variabilita organizační profesionality se odvíjí od počtu organizací, které v ČR poskytují služby kariérového poradenství. Základní překážku pro ztotožnění profesní a organizační profesionality vidím $v$ tom, že organizační profesionalita je vytvářena mezi př́slušníky různých profesí, kteří se „sešli“ $v$ konkrétní organizaci, a profesní profesionalita reprezentuje „názor“ členů relativně uzavřené profesní komunity. $\mathrm{S}$ tím ale také souvisí otázka, jak je nahližena kvalita práce kariérových poradců jako stěžejní hodnota $v$ profesní a jak $v$ organizační profesionalitě. Kvalita v organizační profesionalitě je věcí managementu organizace, ale kvalita v profesní profesionalitě je nahlížena jako projev expertnosti členů profesní komunity. Otázkou zůstává, jak tento rozdíl překlenout či využít. 
$\checkmark$ této situaci a $v$ době, kdy mechanismy mezinárodní podpory institucionalizace kariérového poradenství slábnou (např. zánik evropské sítě ELGPN, ${ }^{12}$ diskuse na úrovni EU o potřebnosti udržet či transformovat sít' středisek Euroguidance), se z hlediska profesionalizace kariérového poradenství v ČR zdá „dobrou“ volbou profesionalizovat kariérové poradenství skrze kvalitu služeb poskytovaných kariérovými poradci $\checkmark$ jednotlivých typech organizací, a vytvořit tak novou profesionalitu (Evetts, 2011).

Nová profesionalita by se mohla stát pomyslným světlem na konci tunelu i pro kariérové poradce, kteři se cítí být na cestě od povolání k autonomní profesi osamoceni, $\mathrm{tj}$. bez výrazné a synergicky působící podpory ze strany profesní komunity, vzdělavatelů i státu.

\section{Literatura}

Allan, G., \& Moffett, J. (2016). Professionalism in career guidance and counselling - how professional do trainee career practitioners feel at the end of a postgraduate programme of study? British Journal of Guidance \& Counselling, 44(4), 447-465.

Amundson, N. (2009). Active engagement: The „being“ and „doing" of career counselling. Richmond, B. C.: Ergon Communications.

Baláž, R. (2017). Profesionalita sociálních pracovníků: Známka kvality, anebo procedurální berlička? Sociální práce, 17(6), 131-151.

Banks, W., \& Martens, K. (1973). Counseling: The reactionary profession. Personnel and Guidance Journal, 51(7), 457-462.

CEDEFOP. (2005). Improving lifelong guidance policies and systems: Using common European reference tools. Luxembourg: Office for Official Publications of the European Communities. Dostupné z https://www.cedefop.europa.eu/files/4045_en.pdf

CEDEFOP. (2009a). Kariérový rozvoj na pracovišti. Průzkum služeb kariérového poradenství pro zaměstnané osoby. Praha: DZS MŚMT pro Centrum Euroguidance.

CEDEFOP. (2009b). Professionalising career guidance: Practitioner competences and qualification routes in Europe. Luxembourg: Office for Official Publications of the European Communities.

CEDEFOP. (2010). Access to success: Lifelong guidance for better learning and working in Europe. Luxembourg: Publications Office of the European Union. Dostupné z http://www .cedefop.europa.eu/files/4092_EN.pdf

Despotovič, M. (2012). Vzdělávání dospělých mezi profesionalizací a profesionalismem. Studia paedagogica, 17(1), 75-90.

Drahoňovská, P., \& Eliášková, I. (2011). Analýza práce a potřeb poradců v oblasti kariérového poradenství na školách. Praha: Núv.

Ehlová, M. (2016). Školní poradenské služby na středních školách poskytované výchovnými poradci. Pedagogika, 66(5), 570-591.

Etický kodex České asociace kariérového poradenství. (2015). Dostupné z http://files.ceska -asociace-kp.webnode.cz/200000067-992ed9b256/Etick\%C3\%BD\%20kodex\%20.pdf

Evans, L. (2008). Professionalism, professionality and the development of education professionals. British Journal of Educational Studies, 56(1), 20-38.

Evans, L. (2012). Úvahy o profesionalitě vzdělavatelů dospělých. Studia paedagogica, 17(1), $129-147$.

Evetts, J. (2003). The sociological analysis of professionalism: Occupational change in the modern world. International Sociology, 18(2), 395-415.

12 The European Lifelong Guidance Policy Network. 
Evetts, J. (2011). A new professionalism? Challenges and opportunities. Current Sociology, 59(4), 406-422.

Evetts, J. (2013). Professionalism: Value and ideology. Current Sociology Review, 61(5-6), 778-796.

Evropská komise. (2004). Draft resolution of the Council and of the representatives of the governments of the member states meeting within the Council on strengthening policies, systems and practices in the field of guidance throughout life in Europe. Brusel: Council of the European Union. Dostupné z http://register.consilium.europa.eu/doc/srv?l=EN\&f $=$ ST $\% 209286 \% 202004 \% 20$ INIT

Evropské společenství. (1989). Komunitární charta základních sociálních práv pracujících. Dostupné z https://www.coe.int/en/web/conventions/full-list/-/conventions/webContent/9119916

Evropské společenství. (2000). Listina základních práv Evropské unie. In Úřední věstník Evropské unie ze dne 14. 12. 2007 (2007/C 303/01). Dostupné z https://eur-lex.europa.eu /legal-content/CS/ALL/?uri=CELEX\%3A12012P\%2FTXT

Freidson, E. (1989). Theory and the professions. Indiana Law Journal, 64(3), 423-432. Dostupné z https: / / www. repository. law. indiana.edu/cgi/viewcontent.cgi?article=1199\&context $=i l j$

Greenwood, E. (1957). Attributes of a profession. Social Work, 2(3), 45-55. Dostupné z http:// www.jstor.org/stable/23707630

Hansen, E. (2007). Kariérové poradenství. Příručka pro země s nízkými a středními př́imy. Praha: DZS MŠMT.

Hiebert, B. (2009). Raising the profile of career guidance: Educational and vocational guidance practitioner. International Journal for Educational and Vocational Guidance, 9(1), 3-14.

Hloušková, L. (2018). Přístupy ve vzdělávání kariérových poradců: od obsahu ke kompetencím? Studia paedagogica, 23(3), 113-138.

Hloušková, L., Knotová, D., Novotný, P., Pol, M., \& Rabušicová, M., et al. (2004). Vzdělávání poradců v České republice. Praha: Národní vzdělávací fond.

Hooley, T., Sultana, R., \& Thomsen, R. (Eds.). (2018). Career guidance for social justice: Contesting neoliberalism. New York: Routledge Taylor \& Francis.

Juklová, K. (2013). Začínající učitel z pohledu profesního vývoje. Hradec Králové: Gaudeamus.

Koščo, J., et al. (1986). Poradenská psychológia. Bratislava: SPN.

Kř́žová, E. (2006). Proměny lékařské profese z pohledu sociologie. Praha: SLON.

Kuczera, M. (2010). Učení pro praxi. Přezkumy odborného vzdělávání a prípravy prováděné OECD. Česká republika. Praha: NúOV.

Maree, J. G. (2010). Brief overview of the advancement of postmodern approaches to career counseling. Journal of Psychology in Africa, 20(3), 361-368.

McCarthy, J. (2004). The skills, training and qualifications of guidance workers. International Journal for Educational and Vocational Guidance, 4(2-3), 159-178.

Mcllveen, P., \& Patton, W. (2006). A critical reflection on career development. International Journal for Educational and Vocational Guidance, 6(1), 15-27.

MPSV ČR. (2019). Kariérový poradce. In Národní soustava povolání. Dostupné z http: / /katalog .nsp.cz/p/karierovy-poradce/103421.html

MŠMT ČR. (2011). Co je regulovaná činnost či povolání? In Uznávání kvalifikací: Základní informace o regulovaných profesích na území ČR. Dostupné z http: / /www.msmt.cz/mezinarodni -vztahy/co-je-regulovana-cinnost-ci-povolani

Národní poradenské fórum. (2013). Usnesení Národního poradenského fóra č. 9 ze dne 30. dubna 2013. Dostupné z http://www.narodniporadenskeforum.cz/uploads/activity /usneseni9-zasedani-npf-18.pdf

Neukrug, E. S. (2012). The world of the counselor: An introduction to the counseling profession. Australia: Brooks/Cole Cengage Learning.

Niles, S. G. (2003). Career counselors confront a critical crossroad: A vision of the future. The Career Development Quarterly, 52(1), 70-77.

Nilsson, P., \& Åkerblom, P. (2001). Kariérové poradenství pro život. Brno: P. F. art. 
60 NúV, \& Trexima (2015a). Kariérový poradce pro ohrožené, rizikové a znevýhodněné skupiny obyvatel. In Národní soustava kvalifikací. Dostupné z https://www.narodnikvalifikace .cz/kvalifikace-1540-Karierovy_poradce_pro_ohrozene_rizikove_a_znevyhodnene_skupiny_obyvatel/revize-694

NúV, \& Trexima (2015b). Kariérový poradce pro vzdělávací a profesní dráhu. In Národní soustava kvalifikací. Dostupné z https://www.narodnikvalifikace.cz/kvalifikace-1538-Karierovy _poradce_pro_vzdelavaci_a_profesni_drahu; http://katalog.nsp.cz/tp/karierovy-poradce -pro-vzdelavaci-a-profesni-drahu/102342.html

NúV, \& Trexima (2015c). Kariérový poradce pro zaměstnanost. In Národní soustava kvalifikací. Dostupné z https: // www.narodnikvalifikace.cz/kvalifikace-1539-Karierovy_poradce_pro zamestnanost/revize-697

OECD. (2004a). Career guidance: A handbook for policy makers. Paris: OECD Publications. Dostupné z http://www.oecd.org/dataoecd/53/53/34060761.pdf

OECD. (2004b). Career guidance and public policy: Bridging the gap. Paris: OECD Publications. Dostupné z https://www.oecd.org/education/innovation-education/34050171.pdf

OECD. (2010). Learning for jobs [OECD Reviews of vocational education and training]. Paris: OECD Publishing. Dostupné z http://www.oecd.org/education/skills-beyond-school/Learning\%20for\%20Jobs\%20book.pdf

Ornstein, A. S., \& Levine, D. U. (2008). Foundation of education. Boston: Hougton Mifflin Company. Dostupné z https://puspitarahayuari.files.wordpress.com/2014/12/allan _c-_ornstein_daniel_u-_levine_foundations_of_education_student_text_tenth_edition 2007.pdf

OSN. (1948). Všeobecná deklarace lidských práv. Dostupné z http: / /www.lidskaprava.cz/uploads/03_dokumenty/04_uvod/00_VDLP_UDHR-.pdf

OSN. (1966). Mezinárodní pakt o hospodářských, sociálních a kulturních právech. Dostupné z https: / / www.vlada.cz/cz/pracovni-a-poradni-organy-vlady/rlp/dokumenty/mezinarodni -pakt-o-obcanskych-a-politickych-pravech-a-mezinarodni-pakt-o-hospodarskych--socialnich -a-kulturnich-pravech-19852/

Patton, W., \& McMahon, M. (2006). Career development and systems theory: Connecting theory and practice. Rotterdam: Sense Publishers.

Peavy, R. V. (2013). Sociodynamické poradenství. Konstruktivistická perspektiva. Praha: DZS pro Centrum Euroguidance.

Píšová, M., Hanušová, S., Kostková, K., Janíková, V., Najvar, P., \& Tůma, F. (2013). Učitel expert: Jeho charakteristiky a determinanty profesního rozvoje (na pozadí výuky cizích jazyků). Brno: MU.

Rada Evropské unie. (2008). Council resolution on better integrating lifelong guidance into lifelong learning strategies. Dostupné z http://www.consilium.europa.eu/uedocs/cms _data/docs/pressdata/en/educ/104236.pdf

Rada Evropy. (1961). Evropská sociální charta. Dostupné z https://www.mpsv.cz/files/clanky /1218/esch.pdf

Rada Evropy. (1988). Dodatkový protokol k Evropské sociální chartě. Dostupné z https://www .mpsv.cz/files/clanky/1219/esch_dp.pdf

Rada Evropy. (1996). Revidovaná Evropská sociální charta. Dostupné z http: //www.euroskop .cz/gallery/5/1684-b9639fb5_72e4_4560_9489_dc6ddba5a898.pdf

Savickas, M. L. (2003). Career counseling in the next decade. The Career Development Quarterly, 52(1), 4-7.

Savickas, M. L. (2008). Helping people choose jobs: A history of the guidance profession. In J. A. Athanasou \& R. Van Esbroeck (Eds.), International handbook of career guidance (s. 97-113). Dordrecht: Springer Netherlands.

Savickas, M. L., Nota, L., Rossier, J., Dauwalder, J.-P., Duarte, M. E., Guichard, J., ... van Vianen, A. E. M. (2009). Life designing: A paradigm for career construction in the $21^{\text {st }}$ century. Journal of Vocational Behavior, 75(3), 239-250.

Sharf, R. S. (2013). Applying career development theory to counseling. Australia: Brooks /Cole Cengage Learning. 
Schiersmann, Ch., Ertelt, B.-J., Katsarov, J., Mulvey, R., Reid, H., \& Weber, P. (Eds.). (2012). NICE Handbook for the academic training of career guidance and counselling professionals. Heidelberg: Heidelberg University.

Suda, Z. (1996). Hesla „profese“, „profesionalizace“. In H. Maříková, M. Petrusek, \& A. Vodáková (Eds.), Velký sociologický slovník (s. 852-853). Praha: Karolinum.

Sultana, R. G. (2004). Guidance policies in the knowledge society: Trends, challenges and responses across Europe. Luxembourg: Office for Official Publications of the European Communities.

Sultana, R. G. (2011). Lifelong guidance, citizen rights and the state: Reclaiming the social contract. British Journal of Guidance \& Counselling, 39(2), 179-186.

Svobodová, D. (2015). Profesní poradenství. Praha: Grada.

Štech, S. (2007). Profesionalita učitele v neoliberální době. Esej o paradoxní situaci učitelství. Pedagogika, 57(4), 326-337.

Van Esbroeck, R., \& Athanasou, J. A. (2008). Introduction: An international handbook of career guidance. In J. A. Athanasou \& R. Van Esbroeck (Eds.), International handbook of career guidance (s. 1-19). Dordrecht: Springer Netherlands.

Vendel, Š. (2008). Kariérní poradenství. Praha: Grada.

Vuorinen, R., \& Kettunen, J. (2017). The European status for career service provider credentialing: Professionalism in European Union (EU) guidance policies. In H. Yoon, B. Hutchison, M. Maze, C. Pritchard, \& A. Reiss (Eds). International practices of career services, credentials, and training (s. 1-15). Broken Arrow, OK: National Career Development Association.

Vyhláška č. 197/2016 Sb., kterou se mění vyhláška č. 72/2005 Sb., o poskytování poradenských služeb ve školách a školských poradenských zařízeních, ve znění pozdějších předpisů.

Watts, A. G. (1994). Occupational profiles of vocational counselors in Europe. Journal of Counseling \& Development, 73(1), 44-50.

Watts, A. G., \& Sultana, R. G. (2004). Career guidance policies in 37 countries: Contrasts and common themes. International Journal for Educational and Vocational Guidance, 4(2-3), $105-122$.

Zákon č. 73/2011 Sb. ze dne 9. února 2011, o Úřadu práce České republiky a o změně souvisejících zákonů.

Zákon č. 435/2004 Sb. ze dne 13. května 2004, o zaměstnanosti (zákon o zaměstnanosti).

Zapletalová, J. (2003). Mapování práce výchovných poradců na základních a středních školách. Výchovné poradenství, 36-37(2), 1-66.

Mgr. Lenka Hloušková, Ph.D.

Ústav pedagogických věd

Filozofická fakulta, Masarykova univerzita

Arna Nováka 1, 60200 Brno

hlouskov@phil.muni.cz 